\title{
PENGARUH KARAKTERISTIK INDIVIDU, KARAKTERISTIK PEKERJAAN, LINGKUNGAN KERJA TERHADAP STRES KERJA KARYAWAN ADMINISTARSI UMUM RUMAH SAKIT UMUM DAERAH PROVINSI NTB
}

\author{
Sulaimiah1, Santi Nururly2, Joko Suprayetno3, Mahyuddin Nasir4 \\ ${ }^{1}$ Fakultas Ekonomi dan Bisnis Universitas Mataram, sulaimiahmia65@gmail.com \\ ${ }^{2}$ Fakultas Ekonomi dan Bisnis Universitas Mataram, srulymtr2013@gmail.com \\ ${ }^{3}$ Fakultas Ekonomi dan Bisnis Universitas Mataram, yetno2006@yahoo.com \\ ${ }^{4}$ Fakultas Ekonomi dan Bisnis Universitas Mataram, mahyuddinnasir@gmail.com
}

\begin{abstract}
This study aims to determine the significant relationship of individual characteristics, job characteristics, work environment either simultaneously or partially as well as dominant influence.

This research is located in West Nusa Tenggara provincial hospital general administration section which consist of 60 people as respondent, research type used is associative research, data collecting method by questionnaire and interview and documentation with linear multiple regression analysis with f test and t test.

The result of this research is significant influence of individual characteristic, work characteristic, work environment simultaneously influence to work stress, while partially individual characteristic and work environment have significant effect to work stress, while dominant influence is individual characteristic
\end{abstract}

Keywords: while dominant influence is individual characteristic

\begin{abstract}
ABSTRAK
Penelitian ini bertujuan mengethuai hubungan signifikan karakteristik individu, karakteritik pekerjaan, lingkungan kerja baik secara simultan maupun secra parsial serta pengaruh dominan.

Penelitian ini berlokasi di rumah sakit umum provinsi Nusa Tenggara Barat bagian adminstrasi yang berjumlah 60 orang sebagai reponden, jenis penelitian yang di gunakan adalah penelitian asosiatif, metode pengumpulan data dengan angket dan wawancara serta dekumentasi dengan alat analisis regresi bergaanda linier dengan uji f dan uji t.

Hasil penelitian yang di dapatkan pengaruh significantkarakteristiindividu, karakteristik pekerjaan,lingkungan kerja berpengaruh simultan terhadap stres kerja, sementara secara parsial karakteristik individu dan lingkungan kerja berpengaruh significan terhadap stres kerja, sementara pengaruh dominan adalah lingkungan kerja.
\end{abstract}

Katakunci: stres kerja, lingkungan kerja, karakteristik individu, karakteritik pekerjaan

\section{PENDAHULUAN}

Stres merupakan adapatasi atas respon individu yang dimediasi oleh individu yang berbeda sebagai konsekuensi atas tindakan, situasi atau kejadian yang memberikan tekanan berlebih terhadap seseorang (Ivancevich et all, 2008: 224). Stres yang berlebihan akan mempengaruhi emosi seseorang yang pada akhirnya dapat 
mempengaruhi bahkan mengganggu pekerjaan maupun prestasi kerja individu itu sendiri. Namun disisi lain stres yang terjadi dapat dicegah tergantung individu itu sendiri dan pemahaman individu terhadap sumber stres itu sendiri. Individu yang mampu mengendalian dan memahami sumber stres dapat membantuorganisasi supaya berjalan lebih efektif. Karakteristik individu itu meliputi umur, jenis kelamin, masa kerja, dan pendidikan.

Selain itu, karaktersitik pekerjaan juga bisa jadi sumber stress yang tidak bisa diabaikan. Karakteristik pekerjaan yang sulit, dan menuntut keterampilan seta keahlian khusus yang sulit bagi individu yang bersangkutan, akan menjadi tekanan yang mengarah ke stress kerja Karakteristik pekerjaan meliputi keterampilan dan keahlian, petingnya pekerjaan bagi masyarakat, kewenangan dalam pekerjaan, dan peran pimpinan. Hal ini dipertegas oleh Robbins (2006) bahwa stres berdampak langsung terhadap stress kerja,

Stres kerja tidak hanya dipengaruhi langsung oleh karakteristik individu, karakteristik pekerjaan tetapi juga faktor yang lain yaitulingkungan kerja. Lingkungan kerja yang meliputi suasana lingkungan kerja seperti suhu, pencahayaan, kebisingan, tata ruang, keamanan dan kenyamanan, tolerensi, serta hubungan antar karyawan. Jika hal tersebut tidak sessuai dan mendukung karyawan dalam bekerja, bahkan menghambat maka akan menimbulkan tekanana bagi karyawan tersebut yang ujungnya akan menimbulkan stres kerja. Pendapat yang tidak jauh berbeda diutarakan oleh Blum (1956) bahwa stres kerja dipengaruhi oleh faktor individual, faktor pekerjaan, dan lingkungan kerja yang merupakan stessor dari organisasi.

RSUD Prov. NTB adalah salah satu sarana kesehatan yang memberikan pelayanan kesehatan yang berkualitas baik prepentif, kuratif maupun rehabilitatif untuk semua lapisan masyarakat di Provinsi Nusa Tenggara Barat. Rumah sakit tersebut dipimpin oleh seorang dikrektur, dan dalam melaksanakan tugas di bantu oleh wakil direktur yang membawahi beberapa pejabat eselon III dan eselon IV.

Gejala stres kerja terlihat pada karyawan RSUD Prov NTB adalah sering terlambatnyatiba dikantor, dan lambat menyelesaikan pekerjaan. Fenomena ini semakin terlihat setelahlokasi rumah sakit dipindahkan dari Jalan Langko di pusat kota di pindahkan ke Jalan Prabu Rangkasari, Dasan Cermen, Sandubayaberjarak $\pm 7 \mathrm{~km}$ dari pusat kota.

\section{Tujuan Penelitian}

Penelitian ini bertujuan untuk menguji secara empiris:

1. Pengaruh negatif signifikan secara simultan karakteristik individu, karakteristik pekerjaan, dan lingkungan kerja terhadap stres kerja karayawan non medis Rumah Sakit Umum ProvinsiNTB

2. Pengaruh negatif signifikan secara parsial karakteristik individu, karakteristik pekerjaan, dan lingkungan kerja terhadap stres kerja pada karyawannon medis Rumah Sakit Umum Provinsi NTB.

3. Pengaruh dominan antara karakteristik individu, karakteristik pekerjaan, dan lingkungan kerja terhadap stres kerja pada karyawan non medis Rumah Sakit Umum Provinsi NTB 


\section{TINJAUAN PUSATAKA}

\section{Penelitian Terdahulu}

Penelitian tentang karakteristik individu, karakteristik pekerjaan, dan dukungan sosial yang berakibat pada stres dan kepuasan kerja pernah dilakukan oleh peneliti diantaranya:

Murtiningrum (2005), meneliti pengaruh konflik pekerjaan-keluarga terhadap dukungan sosial dan stres kerja pada guru SMP. Hasil penelitian menunjukkan bahwa: (1) konflik pekerjaan-keluarga berpengaruh positif dan signifikan terhadap stres kerja, (2) dukungan sosial terbukti memoderasi hubungan variabel konflik pekerjaan-keluarga terhadap variabel stres kerja, (3) dukungan sosial tertinggi adalah dukungan yang bersumber dari pasangan hidup dan keluarga.

\section{Tinjauan Teoritis}

\section{Stres Kerja}

Stres didefinisikan oleh beberapa ahli diantaranya:

1. Gibson et all. (1996) mendefinisikan stres sebagai tanggapan penyesuaian, diperantai oleh perbedaan-perbedaan individu dan/atau proses psikologis yang merupakan suatu konsekuensi dari setiap tindakan dari luar (lingkungan), situasi atau peristiwa yang menetapkan permintaan psikologis dan/atau fisik berlebihan kepada seseorang.

2. Ivancevich et all $(2008,224)$ menjelaskan stres sebagai adapatasi atas respon individu yang dimediasi oleh individu yang berbeda sebagai konsekuensi atas tindakan, situasi atau kejadian yang memberikan tekanan berlebih terhadap seseorang.

Berdasarkan definisi tersebut, dapat disimpulkan bahwa stres merupakan konsekuensi yang diterima oleh individu akibat suatu kejadian maupun tekanan yang berlebihan dan berlawanan dengan apa yang diharapkan.

Faktor utama yang menyebabkan stres (stresor) dikelompokkan menjadi 4 (empat) level yaitu:(1) level individu, (2) kelompok, (3) organisasi, dan (4) faktor diluar organisasi.

\section{Karakteristik Individu}

Setiap organisasi mempunyai sumber daya salah satunya adalah sumber daya manusia yang merupakan sekumpulan karyawan yang terdiri dari berbagai individu yang mempunyai karakteristik yang berbeda antara yang satu dengan yang lain. Karakteristik individu merupakan ciri-ciri khas yang dimiliki oleh masing-masing individu, dimana antara individu yang satu dengan yang lain mempunyai karakteristik yang berbeda dalam menanggapi semua yang terkait dengan aspek kehidupan maupun lingkungan.Ini bisa dilihat dari, jenis kelamin, umur masa kerja dan pendidikan

\section{Karakteristik Pekerjaan}

Karakteristik pekerjaan merupakan sifat dan tugas yang meliputi tanggung jawab, variasi tugas, dan tingkat kepuasan yang diperoleh dari pekerjaan itu sendiri. Karakteristik pekerjaan menurut Hackman dan Oldham (1980) yang dirangkum oleh Robbins (2006: 641) ada 5 (lima) yaitu:

1. Variasi keterampilan yang dibutuhkan (skill variety). 
2. Prosedur dan Kejelasan Tugas (task identity)

3. Kepentingan Tugas (task significant)

4. Kewenangan dan tanggung jawab (autonomy).

5. Umpan balik

\section{Lingkungan Kerja}

Menurut Robbin (2003: 86), lingkungan kerja adalah segala suatu yang ada di sekitar organisasi yang berpotensi menpengaruhi kerja para karyawan, terdiri dari: (1) lingkungan fisik yang meliputi suhu udara, tata ruang, kebisingan, dan penerangan, dan (2) lingkungannon fisik yaitu segala sesuatu yang ada di sekitar organisasi yang di luar fisik seperti susana kerja, toleransi, solidaritas, dan penghargaan karena perstasi yaitu penghargaan pimpinan, perlakuan wajar tanpa diskriminan

\section{Kerangka Konseptual}

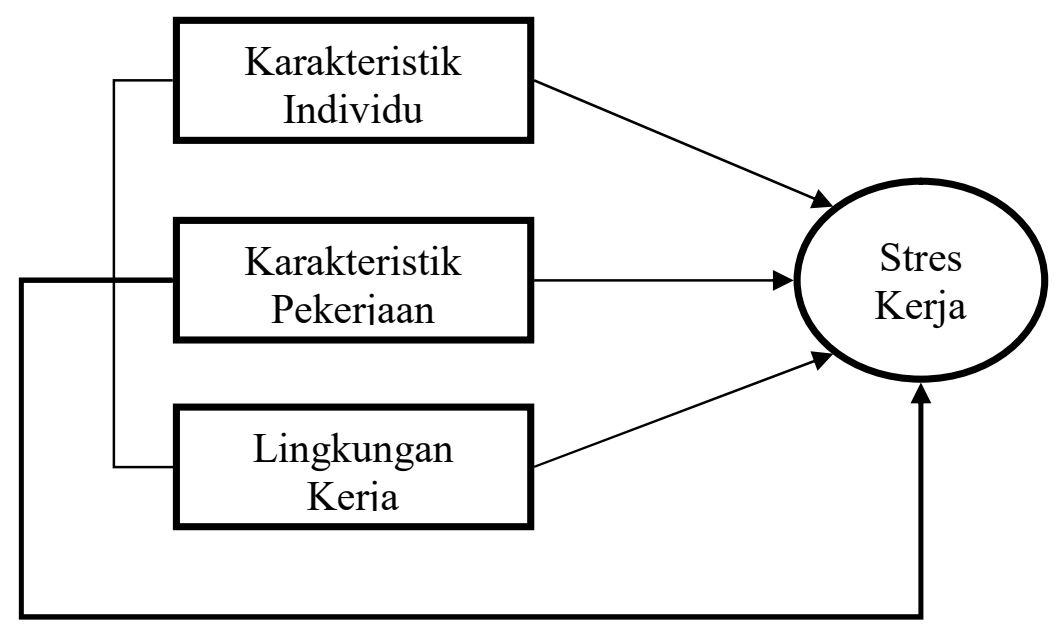

\section{HASIL PENELITIAN DAN PEMBAHASAN}

\section{Identitas Responden}

Tingkat Pendidikan Responden.Tingkat pendidikan responden dalam penelitian ini bervariasi yaitu yang berada di Rumah Sakit Propinsi Nusa Tenggara Barat bagian adminsitrasi Adapun distribusi responden berdasarkan tingkat pendidikan dapat dilihat komposisi pendidikan terbanyja adalah tamatan Diploma 3 (D3), diikuti pendidikan S1 (Strata 1).

Masa Kerja Responden Masa kerja responden dalam penelitian ini bervariasi. Adapun distribusi responden berdasarkan masa kerja dapat dilihatt berbagai masa kerja karyawan Rumah Sakit Umum propinsi Nusa Tenggara Barat bagian Administrasi yang menjadi responden terbesar memiliki masa kerja Masa keeja 4-7 tahun, berada di posisi ke dua yang sma besarnya dengan posisi, di dominasi masa kerja di bawah 4 tahun 


\section{Uji Validitas dan Realibelitas}

Uji Validitas terlihat item corrected item-total correlation $>0,3$ maka bisa dikatakan semua variabel yaitu kaerakteristik individu, karakteristik pekerjaan, ligkungan kerja dan stress kerja dinyatakan Valid

\section{Uji Reliabilitas}

Pengujian reliabilitas dilakukan dengan menggunakan formula alpha pada program SPSS 20.0 for windows. Instrument dikatakan reliabel atau handal apabila memiliki koefisien reliabilitas $\geq 0,6$ dan sebaliknya.

Hasil uji realibel untuk masing-masing variabel yaitu Karakteristik individu, karakteristik pekerjaan, lingkungan kerja dan Stres kerja terlihat semua variabel baik x1, $\mathrm{x} 2, \mathrm{x} 3$ dan Y memiliki alpha cronbach's $>0,6$ yang berarti variabel-variabel tersebut realibel.

Uji Asumsi Klasik, Uji Normalitas, Uji Heterokedastisitas Uji Multikolinieritas, Uji Autokorelasi meemenuhi syarat semuanya

\section{Analisis Regresi Linier Berganda}

$$
Y=6,209-0,466 \mathrm{X} 1-0,099 \mathrm{X} 2-0.439 \mathrm{X} 3
$$

Hasil Analisis Uji t

Coefficients $^{\mathrm{a}}$

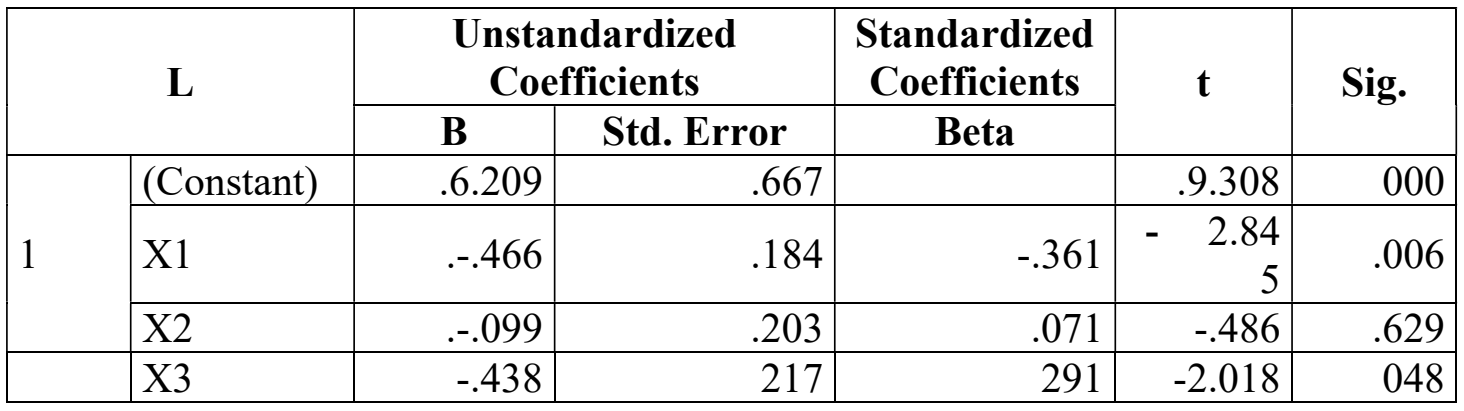

Sumber: Primne di olah

\section{Uji F (Uji Simultan)}

Uji $\mathrm{F}$ digunakan untuk mengetahui apakah variabel bebas yaitu karakteristik Individu (X1) karakteristik Peekerjaani (X2) dan Lingkungan Kerja (X3) secara simultan (bersama-sama) berpengaruh terhadap variabel terikat sters Kerja kerja karyawan (Y), berpengaruh signifikan kerena $\mathrm{f}$ hitung $>\mathrm{f}$ tabel

\section{PEMBAHASAN}

Pengolahan data pada penelitian ini menggunakan bantuan program SPSS 20.0 for windows. Dari hasil analisis regresi, diperoleh persamaan regresi linier berganda sebagai berikut:

$$
Y=6,209-0,466 X_{1}-0,099 X_{2}-0,438 X 3
$$


Dari persamaan tersebut menunjukkan bahwa variabel karakteristik individu variabel karakteristik pekerjaan dan variabel lingkungan kerja mempunyai koefisien regresi bertanda negatif yang berarti bahwa variabel karakteristik individu, karakteristik pekerjaan dan lingkungan kerja berbanding terbalik dengan variabel stres kerja sehingga apabila variabel karakteristik individu, karakteristik pekerjaan dan Lingkungan kerja ditingkatkan maka sters kerja akan semakin menurun.Hal ini sesuai dengan teori yang di gunakan teori Ivancevich, Robiin yang mengatakan bahwa karakteritik individu, Kerakteritik pekerjaan serta Lingkungan Kerja sebagai stressor internal organisasi berpengaruh negarif terhadap stress kerja, ini terlihat dari model stress yang di kemukakan oelh dua ahli tersebut.

Berdasarkan hasil uji t (uji parsial), dapat diketahui bahwa nilai thitung untuk variabel karakteristik individu sebesar -2,846, lingkungan kerja sebesar -2,018 lebih besar dibandingkan dengan ttabel yaitu sebesar -1.674. Dengan demikian hipotesis alternatif (Ha) yang diajukan diterima. Ini berarti bahwa karakteristik individu dan lingkungan kerja berpengaruh signifikan secara parsial terhadap stres kerja. Kecual Karakteristik pekerjaan, ini dimungkinkan karena karakteristik perekerjaan di bagian administrasi yang dianggap tidak terlalu rumit dan tidak membutuhkan tingkat kemampuan khusus yang penting mau bekerja tidak sampai mereka menjadi tertekan dan ahirnya stresskerja yang mereka hadapi.Sementara Karakteristik Individu yang melekat pada diri karyawan yang di dominir oleh karyawan yang usianya masih tergolong muda dan masa kerja yang sangat minim yaitu belum sampai 5 tahun, dengan pengalaman kerja masih tergolongsedikit menuntut banyak pada karyawan yang bersangkutan untuk lebih banyak belajar menegnai pekerjaan, perlu keseriusan tinggi, maka ini merupakan stressot yang cukup berat bagi karyawan sehingga menimbulkan stress, demikian juga lingkan kerja yang baru menuntut mereka harus lebih banyak beradaptasi mengenai bagian -bagian atau alur kerja mereka, lay out kantor yang belum banyak mereka pahami menjadi stressor tersendiri bagi karyawan.

\section{SIMPULAN} berikut:

Dari hasil penelitian yang telah dilakukan, dapatl ditarik kesimpulan sebagai

1. Kearakteristik individu yang melekat pada karyawan bagian adminstrasi rumah sakit umum provinsi Nusa Tenggara Barat, mempunyai pengaruh yang negatif dan signifikan terhadap stress kerja. Ini dapat dilihat dari hasil thitung untuk variabel kkarakteristik individu sebesar $-0,845$ lebih besar dibandingkan dengan ttabel yaitu sebesar - 1.674 .

2. Karakteristik individu dan Lingkungan kerja berpengaruh signifikan terhadap stress kerja karyawan bagian administrasi rumah sakit umum provinsi Nusa karyawan bagian administrasi Rumah sakit umum provinsi Nusa Tengaga Barat, 2,845 untuk karaktristik individu dan Lingkungan kerja sebesar -2,018 dan lebih besar dibandingkan dengan ttabel yaitu sebesar -1.674,

3. Secara simultan variabel, karakteritik individu karakteristik pekerjaan dan Lingkungan kerja mempunyai pengaruh yang negatif dan signifikan terhadap stres kerja karyawan bagian administrasi rumah sait umum provinsi Nusa Tenggara Barat 
4. Variabel yang berpengaruh dominan terhadap stres kerja karyawan bagian adminstarasi rumah sakit umum provinsi Nusa Tenggara Barat adalah Karakteristik Individu.

\section{DAFTAR PUSTAKA}

Adianto, Hari. Yuke Agustin, I.G.A. Happy Trindira. 2005. Jurnal Manajemen \& Kewirausahaan, Vol. 7, No. 2, September 2005: 125-138

Arifin, Zaenal. Eka Afnan Troena, Armanu Toyib dan Umar Nimran. 2010. Pengaruh Karakteristik Individu, Stres Kerja, Kepercayaan Organisasi Terhadap Intention To Stay Melalui Kepuasan Kerja dan Komitmen Organisasi (Studi pada Dosen Tetap Yayasan PTS Makasar). Jurnal Aplikasi Manajemen. Vol. 8 No. 3 Agustus. Hlm. 898 - 905

Baron, R.A \& Byrne, D. (1994). Social Psychology: Understanding Human Interaction. Boston: Allyn \& Bacon.

Blegen, M.A. 1993. Nurses's job satisfaction: a meta-analysis of related variables. INurs. Res .42 (1), $36-41$

Boumans, N. 1990. Het Werk van verpleegkundige in algemene ziekenhuizen: een onderzoek naar werkaspecten en hun invloed op verpleegkndigen. University of Limburg, Maastrict

Castanheira, Filipa and Maria Jose Chambel. 2010. Burnout in salespeople: A threewave study to examine job characteristic's prediction and consequences for performance. Economic and Industrial Democracy. 31 (4), 409 - 429

Djastuti, Indi. 2011. Pengaruh Karakteristik Pekerjaan Terhadap Komitmen Organisasi Karyawan Tingkat Managerial Perusahaan Jasa Konstruksi di Jawa Tengah. Jurnal Bisnis dan Akuntansi. Vol. 13, No. 1 April 2011, Hlm. 1 - 19

Dunseath, J; Beehr, T A; King D W. 1995. Job Stres-Social Support Buffering Effects Across Gender, Education and Occupational Groups in Municipal Workforce. Journal of Public Personnel Administration. Winter 1995, p:60-83.

Deeter, D R and Ramsey, R P. 1997. Considering Source and Types of Social Support: A Psychometric Evaluation of the House and Wells (1978) Instrument. Journal of Personal Selling and Sales Management, Vol. XVII, No.1.1997

Hackman, J.R and Oldham, G. R. 1980. Work Redesign. Addison-Wesley. Massachusetts

Hair, Joseph, F., William C. Black, Barry J. Babin, Rolph E. Anderson and Ronald L. Tatham. 2006. Multivariate Data Analysis. Sixth Edition. Pearson International Edition

Ivancevich, John M., Roberth Konopaske and Michael T. Matteson. 2008. Organizational Behavior and Management. Eight Edition. Mc Graw-Hill International Edition

King, A J C; Peart, M J.1992. The Satisfaction and Stres of Being a Teacher. Worklife Report, Vol.8, No.6, p:12-13.

Kreitner, Robert dan Angelo, Kinicki. 2000. Perilaku Orgnisasi. Buku 2, Edisi 5. Jakarta Penerbit Salemba Empat.

Jansen, Patrick G. M. Ada Kerkstra, Huda Huijer Abu Saad and Jouke Van Der Zee. 1996. The Effect of job characteristic and individual characteristic on job 
satisfaction and burnout in community nursing. International Journal Nursy Study., Vol. 33, No. 4, PP $407-421$

Johnson, J.V. and Hall, E.M. 1988. Job Strain, Work place social support, and cardiovascular disease: a cross-sectional study of a random sample of the Swedish Working Population. Am. J. Publ. Health 78 (10), 1336 - 1342

Karasek, R. A and Theorell, T. 1990. Healty Work : Stres, Productivity and the Reconstruction of Working Life. Basic Book, New York

Luthans, Fred. 2006 . Organizational Behavior. New York : McGraw-Hill

Murtiningrum, Afina. 2005 Analisis Pengaruh Konflik Pekerjaan-Keluarga Terhadap Stres Kerja Dengan Dukungan Sosial Sebagai Variabel Moderasi (Studi Kasus Pada Guru Kelas 3 Smp Negeri di Kabupaten Kendal). Thesis. Unpublished. Program Pascasarjana. Program Studi Magister Manajemen. Universitas Diponegoro

Parasuraman, S and Greenhaus, J H. 1992. Role Stresors, Social Support and Wellbeing Among Two-Career Couples. Journal of Organizational Behavior, Vol.13, No.4 July 1992, p:339-356.

Ratnawati, Intan dan Mona Tiorina Manurung. 2012. Analisis Pengaruh Stres Kerja Dan

Kepuasan Kerja Terhadap Turnover Intention Karyawan (Studi Pada Stikes

Widya Husada Semarang). Diponegoro Journal of Management Volume 1,

Nomor2, Tahun 2012, Hlm. 145--157 http:/lejournal-s1.undip.ac.id/index.php/dbr

Stephen P. Robbins, 2006, Perilaku Organisasi, Jakarta: Indeks.

Tunjungsari, Peni. 2011. Pengaruh Stres Kerja Terhadap Kepuasan Kerja Karyawan

Pada Kantor Pusat Pt. Pos Indonesia (Persero) Bandung. Vol. 1 No. 1, Maret .

Vecchio, Robert, P. 2003. Organizaiotnal Behavior Core Concepts. $5^{\text {th }}$ Edition. Thomson, South Western.

Waluyo, Minto. 2011. Panduan Dan Aplikasi Structural Equation Modelling (Untuk Aplikasi Model Dalam Penelitian Teknik Industri, Psikologi, Sosial dan Manajemen). PT. Indeks. Jakarta

West, PJ. And Collen.1989. Job Stress and Public Sector Occupation, Implications for Personnel Manager. Roppa, Vol. 9 No. 3, Summer, 46-65

http://metro.kompasiana.com/2012/02/27/polisi-satpol-pp-442746.html 